\title{
A construção do usuário na cultura audiovisual do YouTube
}

The construction of the user in the audiovisual culture of YouTube

\section{Sonia Montaño}

Professora e pesquisadora do Programa de Pós-Graduação em Comunicação da Universidade do Vale do Rio dos Sinos. Doutora em Ciências da Comunicação. Autora do livro "Plataformas de vídeo, apontamentos para uma ecologia do audiovisual da web" (2015).

<soniam@unisinos.br>

\section{RESUMO}

O artigo apresenta uma cartografia inicial dos modos em que o usuário é construído no YouTube e formula problemas de conhecimento para os estudos contemporâneos da imagem e do audiovisual na web. Ao longo dos dez anos de existência, a plataforma foi construindo o usuário associado a sentidos diversos, valorizando sua condição de amador ou, mais recentemente sua condição de criador, desenvolvedor e empreendedor. Essas relações são problematizadas em diálogo com autores como Benjamin e Certeau, que discutem o lugar da técnica na cultura e nas relações entre produção e consumo e os modos de produção por apropriações e usos no cotidiano. As contradições entre um usuário programado pela interface e um usuário que a reprograma demonstra um estágio transitório e complexo da técnica e, por isso, fértil para os estudos do audiovisual e da comunicação.

Palavras-chave: Usuário. Plataformas de vídeo. YouTube.

\begin{abstract}
This article presents an initial mapping of the ways in which the user is constructed on YouTube and raises questions that are problems of knowledge for contemporary studies on image and audiovisual content on the web. Over its ten years of existence, the platform constructed its users associated to several meanings, valuing his amateur status, or, more recently, that of the creator, developer and entrepreneur with audiovisual content as the center of this entire process. These relationships are discussed in dialogue with authors such as Benjamin and Certeau, who discuss the place of the technique in culture and in the relationships between production and consumption, besides ownership and use in everyday life. The contradictions between a user programmed by the interface and a user who reprogrammed demonstrates a transitional and complex technical stage. It is therefore an important stage for audiovisual and communication studies.
\end{abstract}

Keywords: User. Video platforms. YouTube.

\section{INTRODUÇÃO}

Em 2006, a revista Time fez uma escolha até então inusitada. Ao divulgar a "Pessoa do Ano", prática que iniciou em 1927 em que é escolhida uma pessoa ou um grupo considerado com maior influência social, a "pessoa" escolhida foi "você" (You), um pronome de tratamento pessoal explicado como "conteúdo gerado pelo usuário da internet", referindo-se ao crescimento e à influência dos 
conteúdos on-line produzidos pelos usuários em blogs ou sites como YouTube, MySpace e Wikipedia, particularmente citados. ${ }^{1}$

Passaram-se dez anos desse fato e essa figura que, embora não muito tranquilamente, ${ }^{2}$ se concorda em chamar de usuário e os modos como ela foi se construindo na web e fora dela, parece estar no centro de diversas práticas e construções conceituais, imagéticas, midiáticas e audiovisuais, tornando-se assim, um desafio para o campo da comunicação.

Uma questão importante na popularização do termo e nas práticas que caracterizam esse usuário surge com a chamada web 2.0, ${ }^{3}$ um marco para enunciar o usuário como centro da internet e a internet com o usuário conectado como centro da vida contemporânea. Como constata Manovich (2014), centenas de milhões de pessoas escrevem blogs, sobem fotografias e vídeos a páginas de compartilhamento, empregando ferramentas de softwares gratuitas que uma década antes teriam custado milhares de dólares. Mas o próprio autor (Manovich, 2011) também adverte que o modo de pensar esse usuário ainda é um desafio acadêmico:

Ao celebrar o conteúdo gerado pelo usuário e implicitamente qualificá-lo como "alternativo" e "progressista", as discussões acadêmicas, muitas vezes, ficam longe de perguntar certas questões críticas básicas. Por exemplo: em que medida o fenômeno do conteúdo gerado pelo usuário é impulsionado também pelas próprias empresas de mídias sociais - que estão no negócio em busca de obter o máximo de tráfego possível para seus sites para que eles possam ganhar dinheiro com a venda de publicidade e os usos de seus dados? (Manovich, 2011, p. 286).

1 Conferir a edição da Time: Person of the Year de. 2006. Disponível em: http://content.time.com/ time/covers/0,16641,20061225,00.html Acesso em: mar. 2014.

2 Alex Primo (2005, p. 2) problematiza o conceito de usuário por acreditar que o termo "deixa subentendido que tal figura está à mercê de alguém hierarquicamente superior, que coloca um pacote a sua disposição para uso (segundo as regras que determina)". Aqui, o termo usuário quer ressaltar o caráter manipulável, usável, tátil do audiovisual da web. Estou seguindo mais na perspectiva de Michel de Certeau (2001), conforme veremos logo a seguir.

3 Definida por O'Reilly (2005) como núcleo ao redor do qual gravitam algumas práticas comuns de boa parte dos sites, a web 2.0 destaca conceitos como o de plataforma que viabiliza funções on-line que antes só poderiam ser conduzidas por programas instalados em um computador. O autor enfatiza o desenvolvimento da "arquitetura de participação", que aproveitaria a "inteligência coletiva", já que o sistema informático incorpora recursos de interconexão e compartilhamento. Dessa forma, quanto mais pessoas na rede, mais arquivos se tornam disponíveis. Isso demonstra, segundo O'Reilly, um princípiochave da web 2.0: os serviços tornam-se melhores quanto mais pessoas os usarem, o que demanda na sua própria técnica da presença do usuário. 
Hánecessidadedepensarmelhoresseusuáriona interfacecontemporânea e na gráfica, como um sujeito que faz parte dela (há inúmeras presenças dele na interface) e ao mesmo tempo a modifica com seus usos e apropriações.

Disperso na interface, o usuário, se é que podemos falar dele em forma singular, é construído na web cada vez mais relacionado a um cadastro. Ele inicia seu trajeto preenchendo dados que lhe atribuem um login: sua porta de acesso para redes sociais e plataformas. Este login permite não só entrar na página cadastrada, como acessar muitas outras e deixar rastros do seu percurso gerando dados. Entre os dados gerados estão os sites pelos que navega, os produtos que consome (seja de forma paga ou gratuita), os posts e comentários que deixa, os vídeos que assiste, comenta ou posta. O usuário na interface contemporânea está diretamente associado à geração de um banco de dados, ${ }^{4}$ dados que constituem quase seu próprio corpo na rede. Esse percurso mostra que a ontologia do usuário é feita de dados (tenham eles a forma de texto, imagens, vídeos etc.) e de trânsito, conjunto de práticas e operações mediado por softwares. ${ }^{5}$

Se pensarmos, então, essa grande interface cultural da comunicação contemporânea, podemos ver espaços múltiplos onde o usuário aparece de diversas formas. Cabe aqui pensarmos melhor nessa presença particularmente no que diz respeito ao usuário na interface das plataformas de vídeo. Elas nos interessam, e particularmente o YouTube, por entendermos que há nesses espaços um modo de enunciação do usuário especialmente complexo, que mostra uma tendência de nossa contemporaneidade, que chamamos de audiovisualização da cultura. Contudo, é preciso discutir antes alguns autores que vêm refletindo sobre o conceito de técnica no centro da cultura e particularmente da cultura midiática concebendo nela a construção do usuário, embora não necessariamente chamado dessa forma.

\section{O LUGAR DO USUÁRIO NA TECNOCULTURA}

Sob diversas perspectivas e em diferentes épocas, alguns autores (Manovich, 2011, 2014; Toffler, 1980; Certeau, 2001; Benjamin, 1996, entre outros) pensaram o lugar do usuário nas mídias e na cultura que lhe foram contemporâneas. Pensar o usuário a partir desses autores é pensá-lo num estágio da técnica específico de cada época e nas relações instauradas pelo aparelho de produção dessa época.

4 Um interessante artigo sobre as consequências desses rastros que deixamos e o modo de exercício da vigilância na web foi publicado por Fernanda Bruno (2006).

5 Sobre isso, ver Manovich (2014) e sua reflexão sobre a sociedade do software. 
Benjamin (1996), ao tentar entender as mudanças entre os séculos 19 e 20, se depara com um tipo de público cada vez mais devorador de mercadorias do qual percebe duas tendências: a de aproximar todas as coisas e a de acabar com o caráter único delas (sua aura), assumindo o domínio o mais próximo possível com sua imagem, sua cópia ou reprodução. O autor pensa essas mudanças a partir dos novos públicos e sua relação com a natureza do aparelho produtivo. Nessas novas condições, Benjamin busca entender como acontecem as relações entre tendência e qualidade de uma obra (ou também de uma mídia), tentando perceber na técnica as relações entre estética e política.

Em O autor como produtor (escrito em 1934), Benjamin (1996) refletia sobre a técnica literária e reagia a uma visão instrumental da literatura pensada a serviço de fins políticos. Para o autor, a tendência política correta inclui uma tendência literária, e é essa tendência literária contida implícita ou explicitamente em cada tendência política que constitui a qualidade de uma obra. Estabelece, assim, uma distinção decisiva entre quem abastece o aparelho de produção literária e quem o modifica. Que o consumidor se torne um produtor, um especialista, um interessado é o modo como Benjamin pensa o usuário (embora não usou esse termo) na tecnocultura de sua época. Entretanto, cabe também ao produtor abrir o aparelho de produção de alguma forma para que quando o leitor exercite sua leitura aprenda e se interesse pelo ofício de escritor.

Reflexão semelhante desenvolveu em relação ao teatro na obra O que é o teatro Épico?, escrita em 1931. Benjamin (1996) nota que as mudanças não estavam no drama e sim no palco. Ao desaparecer a orquestra, desparece o abismo que separava atores e público e surge um novo espaço social que permite a reinvenção do teatro feita por Brecht, por exemplo, enquanto outros seguiam produzindo teatro como se essa mudança não tivesse acontecido. $O$ teatro épico ordena experimentalmente os elementos da realidade e não trata de "retratar a realidade", a fim de que as condições do cotidiano sejam afastadas do espectador e não naturalizadas, de tal modo que ele as encontre no final desse processo. Dessa forma, o espectador desenvolve seu interesse e se torna um especialista, mas também dessa forma ele se aliena de sua própria realidade e reconhece elementos que não lhe são visíveis no cotidiano. A interrupção é o elemento-chave para isso. É aí quando:

O olhar do estranho é o olhar do próprio espectador que se vê apanhado pelo assombro da descoberta de uma situação comum, habitual. $\mathrm{O}$ assombro aqui assume um papel central, pois 'é no indivíduo que se assombra que o interesse desperta', ao passo que a alienação aparece positivamente, no sentido de uma descoberta 
daquilo que foi esquecido, mas cotidianamente é conhecido de todos. Afastando-se da situação é que se a descobre com o assombro do seu absurdo, humor etc. A transformação das massas em especialistas é possível graças ao caráter (dialeticamente) alienante da interrupção da ação. Sem tal distanciamento, não há a descoberta das situações, mas apenas a sua reprodução, tampouco haveria o estímulo ao pensamento, já que um dos princípios do teatro épico é exatamente cumprir uma função organizadora do seu público, ou seja, o público operário (Araújo, 2008, p. 72).

Para Benjamin (1996), essas formas do teatro épico correspondem às formas técnicas contemporâneas, como o cinema e o rádio. Para ele o avanço dos meios técnicos da produção cultural forjaria ao mesmo tempo em que dissolve o muro que separa autor e público.

Em A obra de arte na era de sua reprodutibilidade técnica (escrita em 193536), Benjamin (1996) vê no cinema uma técnica em que produção e reprodução são inseparáveis e que deixa evidente o direito de qualquer espectador a ser filmado e aparecer na tela. ${ }^{6}$ Além disso, o cinema muda as condições de recepção: o público se distrai e, distraído se torna um examinador, um aficionado. $O$ caráter coletivo de sua produção e sua inserção social daria ao cinema características políticas relevantes já que muda o comportamento do espectador diante da arte e o torna um semiespecialista e não mais um consumidor. No caso do cinema teria, na visão do autor, o potencial de

[...]mostrar o imperceptível com a dinâmica de seus décimos de segundo que fez saltar o mundo carcerário de nossos bares, de nossos escritórios e habitações, de nossas estações e fábricas, que pareciam aprisionar-nos sem esperança e agora empreendemos, entre seus escombros dispersos, viagens de aventuras (Benjamin, 1996, p. 189).

Um olhar complementar ao benjaminiano desde um lugar de fala muito diferente nos é proporcionado por Michel de Certeau (2001). Em A Invenção do cotidiano, o autor pensa naquilo que normalmente se chama de consumo como um modo de produção, um uso, e os habitualmente chamados de consumidores são pensados como usuários e produtores. A uma produção racionalizada, expansionista, barulhenta, espetacular e centralizada corresponderia, para ele,

6 Pelas características técnicas do cinema, o ator não entra no seu papel como o faz o ator de teatro, ele interpreta diante de um aparelho de maneira fragmentada e descontínua e fica de fora da escolha das cenas finais, o que é dado a um conjunto de técnicos. Ele se autorrepresenta em diversos momentos, diversas vezes e em diversas situações, seja numa cena de susto ou numa reação emocionada, o que o torna semelhante as massas que se autorrepresentam diante de um aparelho nas fábricas. 
outra produção quase invisível e dispersa porque não se faz notar com produtos próprios, mas "nas maneiras de empregar os produtos impostos por uma ordem econômica dominante" (Certeau, 2001, p. 39).

Certeau cunhou o termo usuário bem antes do uso contemporâneo que ele tem para se referir ao autor do desvio ou a apropriação de qualquer produto ou processo já previamente definido por um sistema produtor. Haveria no termo o reconhecimento de uma força criadora que gera uma "bricolagem" com a cultura dominante. Nessas transformações o autor percebe as mais diversas metamorfoses que dão a ver os interesses desses usuários.

Numa releitura de Certeau, Manovich (2011) adverte que a produção das empresas (chamadas por Certeau como estratégias) e a produção dos consumidores (também chamadas por ele de táticas) estão agora numa relação diferente à dos anos 1980 em que o livro de Certeau foi publicado. Para indústrias que nasceram digitalmente, as empresas já viriam com uma série de possibilidades para o usuário escolher e formar sua interface. Algumas marcas apresentam aos consumidores a possibilidade de personalizar seus pedidos entre uma ampla gama de produtos como algo característico do paradigma "2.0", em que os produtos já vêm pensados para serem hackeados, e os designs para serem remixados.

Se bem esse contexto próprio da cultura midiática atual deve ser levado em conta, pensar com Certeau as práticas do cotidiano audiovisual da plataforma ou de qualquer mídia, ainda se torna extremamente necessário já que, no estágio provisório da técnica em que nos encontramos, esses usos constroem verdadeiros processos de comunicação e criação não previstos que vão tensionando e contribuindo para a construção identitária e para os modos de operar dessa mídia.

Certeau não estava preocupado em avaliar os processos de reinvenção dos usuários e sim conhecê-los, explorá-los, entender suas poéticas:

Por exemplo, a análise das imagens difundidas pela televisão (representações) e dos tempos passados diante do aparelho (comportamento) deve ser completada pelo estudo daquilo que o consumidor 'fabrica' durante essas horas e com essas imagens (Certeau, 2001, p. 39).

Se esse estudo, no modo em que foi pensado e realizado pelo autor, demandou diversas metodologias que chegassem à observação das fabricações realizadas pelos usuários, hoje e no objeto que nos ocupa, essas apropriações ficam inscritas em superfícies, imagens técnicas (Flusser, 2002), 
que o usuário produz a partir das dadas pela plataforma, mas também outras não programadas. As ações do usuário no fluxo da plataforma ficam inscritas em processos midiáticos que suscitam outras sociabilidades, outras formas do audiovisual, outros gêneros, outros valores que orientam e compõem as montagens audiovisuais.

Essas referências teórico-metodológicas e a metodologia de análises das imagens da interface audiovisual do YouTube, que desenvolveremos a seguir (Kilpp, 2010), são de fundamental contribuição para um primeiro olhar cartográfico sobre a presença do usuário no YouTube.

\section{O USUÁRIO NO YOUTUBE}

Alguns autores como Burguess e Green (2009) já explicaram que o YouTube, atualmente a principal plataforma de compartilhamento de vídeos, foi criada em 2005. Desde 2007 pertence à empresa Google que recentemente passou a se chamar Alphabet Inc., ${ }^{7}$ um conglomerado que possui várias empresas que se agrupavam sob o nome Google, inclusive o site de busca que ainda continua com este nome. É importante considerar sempre este conjunto (Flusser, 2002, pensaria o conjunto como metajogos, de meta-aparelhos com metaprogramas) já que o usuário para a empresa sempre é considerado um usuário do universo Google (agora Alphabet) e não dos produtos separados. A empresa se constrói como se fosse um grande ecossistema que cobre todas as necessidades demandadas no cotidiano das mais pontuais, como uma agenda, a mais especializada: como a manipulação genética. Mas esse assunto especificamente ocupará outro artigo. Voltemos neste momento ao usuário no YouTube (e perceba-se que não dissemos do YouTube, o usuário é de todos os produtos da empresa).

Este espaço de compartilhamento tem uma quantidade imensa de imagens audiovisuais que são produzidas e postas em circulação na contemporaneidade. Esse fato, que se tornou possível pela enorme produção de dispositivos e softwares do audiovisual (a sociedade do software pensada por Manovich, 2014), tem, nas plataformas de vídeo, sua mais expressiva dinâmica de multiplicação e aponta para dois grandes metaprogramas (Flusser, 2002) da contemporaneidade: a audiovisualização da cultura e a softwarização do audiovisual. Mas aponta também para a construção dessa figura: o "you", o

7 A empresa funciona como um grande guarda-chuva para diversos empreendimentos de $\mathrm{A}(\mathrm{ndroid}) \mathrm{a}$ projeto Z(ero), por isso o nome Alphabet. A lista de todas as empresas podem ser conferidas na matéria publicada no Site G1, disponível em: http://g1.globo.com/tecnologia/noticia/2015/08/alphabet-veja-listade-todas-letras-da-nova-google-de-ndroid-zero.html 
"usuário" audiovisualmente ${ }^{8}$ construído e para os modos em que ele vem sendo ressignificado nos últimos anos nas interfaces da plataforma.

Esses ambientes não são, então, simplesmente espaços neutros que contêm vídeos. Neles, os vídeos obedecem à certa organização e a uma espacialização, uma montagem que os enuncia de outro modo e sugere (e disponibiliza para o usuário) usos diversos. $\mathrm{Na}$ interface, os elementos que rodeiam o vídeo incluem o usuário e, também, uma multiplicidade de direções nas quais esse usuário pode se encaminhar audiovisualmente (assistir um dos vídeos relacionados, por exemplo) ou encaminhar o vídeo (compartilhá-lo com outro usuário, por exemplo). Trata-se de um modo de interfacear usuário e vídeo na plataforma e na web em geral que é inédito em referência aos modos como outras mídias audiovisuais estabeleciam relações entre os espectadores e entre estes e as imagens audiovisuais.

Para pensar melhor e decodificar estas imagens, é preciso ainda explicar brevemente o procedimento metodológico que nos permite adentrá-las e decifrá-las. Trata-se da metodologia das molduras: ela parte de uma cartografia e dissecação de imagens para compreender os sentidos produzidos nos confins desses territórios audiovisuais.

Proposta por Kilpp (2010), a metodologia das molduras pensa o audiovisual como imagens técnicas, como mundos tecnicamente construídos a ser decodificados para decifrar seus sentidos. A metodologia implica inicialmente em três eixos conceituais: molduras, ethicidades e imaginários. Os eixos são atravessados pelos quatro conceitos principais da obra de Bergson (1999), que são a intuição, o elã vital, a duração e a memória, e pelos conceitos de imagicidade e cinematismo propostos por Eisenstein (1990), conceitos a partir dos quais a metodologia visa autenticar o audiovisual presente em cada mídia. Em sua processualidade, parte da dissecação de molduras discretas que são próprias de cada mídia e mostram montagens, enquadramentos e efeitos de sentido. As molduras são os quadros e territórios de experiência e significação de construtos midiáticos (chamados também de ethicidades), cujo sentido último é agenciado por conta dos imaginários minimamente compartilhados entre todos os partícipes de processos comunicacionais. Na relação desses elementos tecnoculturais, encontram-se, contagiam-se reciprocamente e atravessamse ambientes midiáticos e ambiências socioculturais que os produzem. Essa metodologia tem se mostrado eficiente para a desconstrução de sentidos em

8 Em estudo anterior, desenvolvemos uma distinção entre vídeo e audiovisual na web. O audiovisual está formado por quatro elementos: o vídeo, o usuário, a interface e o ambiente. 
diversas mídias audiovisuais como o cinema, a televisão, a internet, os contextos urbanos e as mídias móveis.

Ao pensarmos então o usuário como construto (ethicidade), o pensamos como uma imagem técnica e nela como uma duração (Bergson, 1999), uma memória ou elã vital que se atualiza das mais diversas formas na mídia em questão. Uma primeira cartografia de molduras que dão sentidos ao usuário no YouTube nos levou a dissecar algumas interfaces onde ele parece estar mais intensamente significado. Dessa forma, detemo-nos principalmente em três momentos da plataforma em que a produção de sentido sobre o usuário parece estar em destaque: a home, página principal do YouTube; algumas páginas institucionais que se enunciam como "escolas" formadoras de usuários e os usos e apropriações efetivos que só podem ser percebidos na prática cotidiana, retomando a linguagem de Certeau, entre as diversas interfaces.

Este artigo é um recorte da pesquisa "O usuário como construto nas interfaces do YouTube", que está nos seus inícios e é financiada pelo CNPq.

\section{O USUÁRIO/CANAL NA HOME DA PLATAFORMA}

O usuário moldurado como um "canal" é uma das referências mais presentes e antigas na construção do YouTube; contudo, o modo de construir essa ethicidade foi mudando ao longo dos últimos anos. Refletimos aqui sobre três designs de interface da home da plataforma em que as mudanças ocorridas mostram um usuário que vai sendo ressignificado neste espaço.

As observações sobre a construção do usuário como canal aqui correspondem à dissecação de interfaces da home nos anos de 2010, 2012 e 2016, nas que podemos perceber algumas molduras que permanecem e outras que vão sendo introduzidas ou substituídas. Entretanto, antes de observarmos estas interfaces é preciso compreender os sentidos que essa página tem nas práticas mais habituais de construção de sites na web.

Seja homepage, página inicial, ou principal ou página de entrada reconhecemos como algo natural que qualquer site tenha um ponto de partida. O nome com que ficou conhecida essa página com sua conotação de lar (home) parece ser enunciativo de um certo equilíbrio para um universo que funciona na extrema fragmentação e convida constantemente a desviar o rumo. Navegamos por uma superfície com um conjunto de elementos - textos, gráficos, imagens em que a grande maioria funciona como link para outras páginas da plataforma. As homes e as páginas em geral são um tipo de lar sem teto ou paredes; seriam, como as chama Santaella (2007), dados habitáveis: 


\begin{abstract}
Dados podem se tornar arquitetônicos e habitáveis, de modo que o ciberespaço e a arquitetura do ciberespaço são uma só e mesma coisa. Entretanto, trata-se de uma arquitetura líquida, que flutua. Por isso, o ciberespaço altera as maneiras pelas quais se concebe e percebe a arquitetura, de modo que torne nossa concepção da arquitetura cada vez mais musical. Pela primeira vez, o arquiteto não desenha um objeto, mas os princípios pelos quais o objeto é gerado e varia no tempo. [...] uma arquitetura desmaterializada, dançante, difícil, etérea, temperamental, transmissível a todas as partes do mundo simultaneamente, só indiretamente tangível, feita de presenças sempre mutáveis, líquidas (Santaella, 2007, p. 17).
\end{abstract}

O sentido tradicional de lar como um lugar delimitado e aconchegante se transforma na web, já que essa página inicial nunca convida a permanecer no lugar, essas "presenças sempre mutáveis" estão na natureza do dado e na interface como se apresenta na maior parte dos sites composta basicamente de links. Seriam lares que nos proporcionam experiências mais semelhantes às dos aeroportos e rodoviárias do que as das nossas casas, espaços para transitar em algumas direções possíveis. Entre as páginas, a home é uma moldura importante para todo o site, nela se apresentam as possibilidades de navegação e se o faz principalmente com as barras de navegação que estão presentes nos panoramas web com fortes sentidos de orientar nosso movimento e nos tirar da situação de "perdidos" ou "parados". Sentir-se em casa no meio do caos é sinônimo de encontrar caminhos para andar. As barras de navegação situam o usuário, sugerindo próximos destinos nos quais fazer cliques. É por isso que homes e barras de navegação se transformam em espaços de significação importantes que dão sentidos a todas as páginas.

No YouTube, há duas barras de navegação que estão presentes em todas as páginas e, portanto, enunciam sentidos de ubiquidade, embora diferentes para a plataforma. A primeira está centrada no vídeo e principalmente no usuário e localiza-se no topo direito da página. A segunda enuncia sentidos principalmente sobre a plataforma e se situa no final da página oferecendo entre seus links alguns dedicados a ensinar o usuário a se constituir como tal.

Ao acessar a plataforma encontramos o botão "login", moldura que leva a introduzir o nome de usuário e senhas cadastrados para acessar a uma home personalizada. É aí que se abre o espaço do canal.

A denominação "canal" é uma referência metafórica relacionada ao que conhecemos por canais em TV, e que, no entanto, ressignifica tais territórios, ainda que sejam nominados da mesma forma. Em primeiro lugar, isso acontece em virtude das relações estreitas entre canal e usuário, que, na TV, acontecem 
de um modo muito diferente, reforçando na web sentidos sobre um possível controle de qualquer indivíduo sobre a produção e a emissão. O usuário seria aqui o dono de um canal no qual há espaço para vídeos, um território que pertence ao usuário (só pelo fato de se ter cadastrado e gratuitamente). A construção identitária deste usuário/canal acontece particularmente nas barras de navegação, mas tende a moldurar todas as interfaces do YouTube a partir dessa presença.

Entretanto, se em algum momento da história da plataforma usaramse esse tipo de estratégias que aproximava e ao mesmo tempo diferenciava o YouTube daTV, hoje essas práticas parecem ter sido naturalizadas como próprias da plataforma.

\section{- Figura 1 - Home do YouTube de 2010, com destaque para a janela do canal/ usuário}

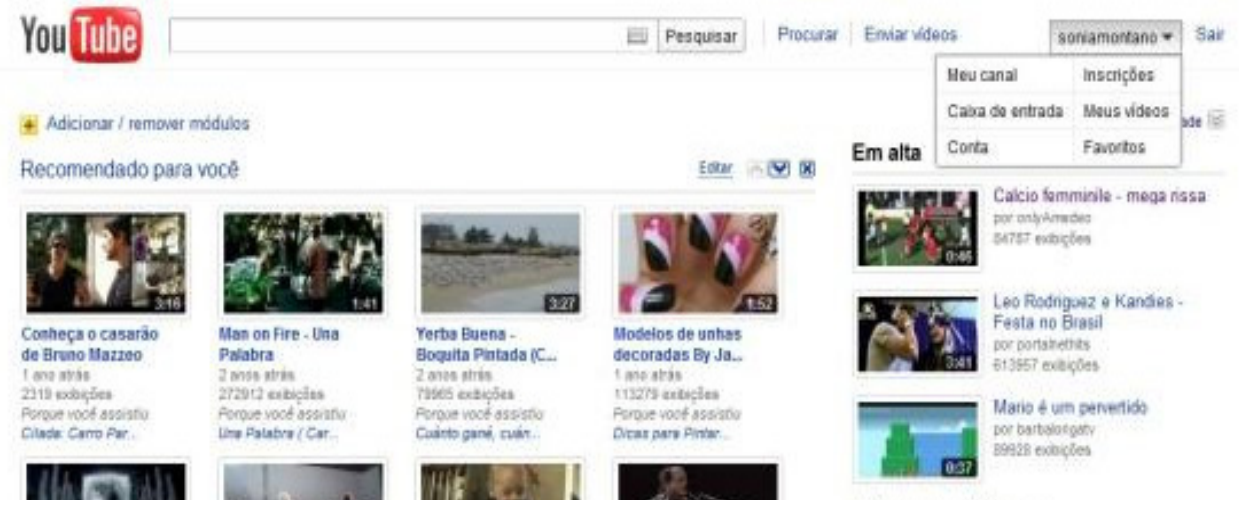

Fonte: YouTube, 2010.

Nas três interfaces observadas aqui, temos a presença do canal/usuário na barra de navegação principal, no canto superior direito. O usuário seria aquele que moldura a home e a plataforma como um todo, já que essa barra de navegação está presente em todas as páginas e está diretamente relacionado a vídeos (sejam eles para assistir ou para enviar). Ambas ethicidades, usuário e vídeo estão diretamente relacionados nos modos em que são construídas no YouTube.

Entretanto algumas molduras discretas vão ressignificando ambas ethicidades. Na interface de 2010 (figura 1), a moldura do usuário apresentava os links: "meu canal"; "caixa de entrada"; "conta" "inscrições"; "meus vídeos" e "favoritos", links que remetiam para o território do canal/usuário e apontavam mais para espaços do que para ações. O usuário dessa interface era alguém 
que, principalmente, possuía um espaço online para ver, interagir com e enviar vídeos.

- Figura 2 - Home do YouTube de 2012, com destaque para o canal/usuário

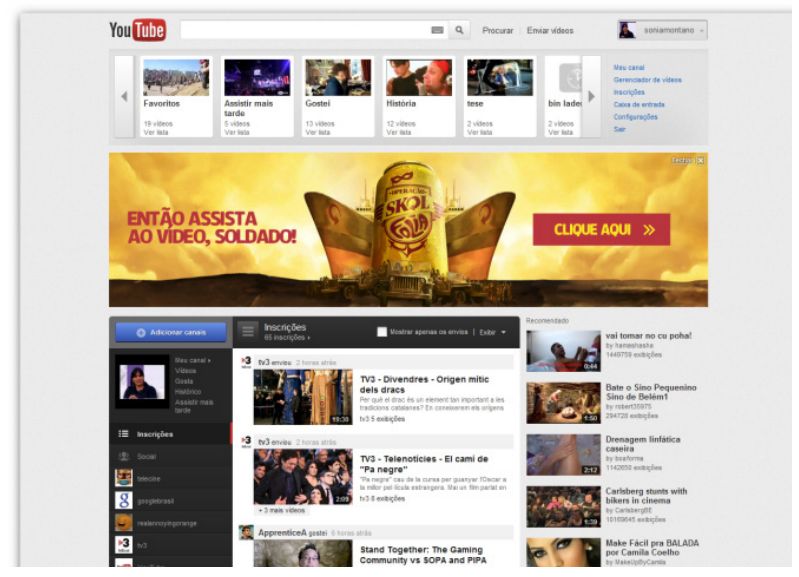

Fonte: YouTube, 2012.

Figura 2a - Barra de navegação do canal na barra de navegação principal

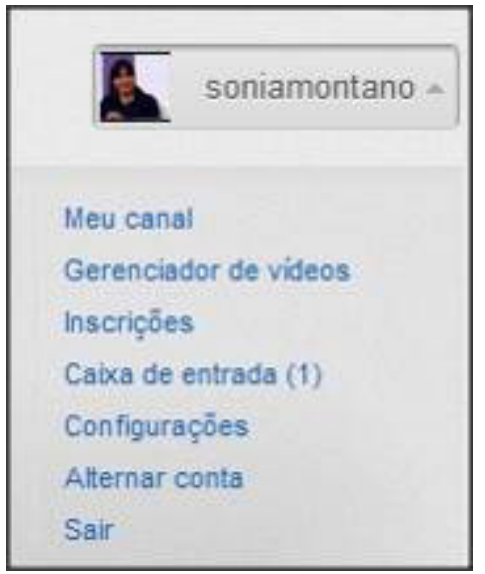

Fonte: YouTube, 2012.

Já a home de 2012 (figura 2) traz a presença do usuário de forma mais destacada: em duas barras de navegação. A superior direita, com o nome do usuário e a foto dele e a lateral, também com a foto e um conjunto de links. Neste segundo momento, o usuário ganha uma personalização maior com essas duas presenças que têm destaque para sua foto, sendo assim moldurado como protagonista em relação a todos os outros elementos da interface (menos a publicidade que ocupa o espaço principal da home). Mas não é só o lugar 
ocupado pelo usuário na montagem espacial ${ }^{9}$ da plataforma que chama a atenção, há novos sentidos relacionados a ele.

Os links da barra de navegação superior (figura 2a) são um pouco diferentes da interface anterior. São eles: "meu canal"; "carregar vídeos"; "inscrições"; "caixa de entrada"; "configurações" "alternar conta" e "sair". Podemos ver ali a introdução de links que integram verbos, ações como a de "carregar vídeos" no lugar de "meus vídeos"; "alternar conta" e "sair". Se os links anteriores colocavam o usuário em contato principalmente com seu canal, seu espaço, o design de 2012 o enuncia principalmente relacionado ao universo dos vídeos (os próprios e os enviados por outros usuários), assim como as ações que pode realizar nestes espaços.

\section{- Figura 2b: listas de vídeos do canal/usuário na barra de navegação principal}

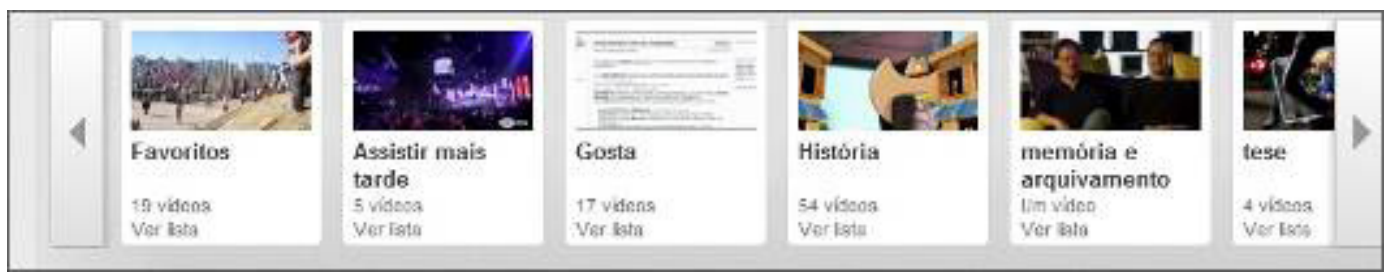

Fonte: YouTube, 2012.

Contudo, a moldura do usuário que mais se diferencia da interface anterior e que também se abre ao apoiar o mouse no login é uma janela que exibe listas de vídeos formadas pelo usuário (figura 2b). O usuário é alguém que cria listas, coleções de vídeos. O modo de formar essas listas acontece de duas formas: por uma ação específica do usuário que seleciona alguns vídeos e os agrupa dando um nome à lista ou pelo seu percurso na plataforma. A lista "assistir mais tarde", por exemplo, é formada por aqueles vídeos em que o usuário clicou no botão disponibilizado pela plataforma que permite assistir em outro momento ou a lista "histórico", que é formada pelos últimos vídeos assistidos pelo usuário. Nesse conjunto de coleções, não há espaço para os vídeos enviados pelo próprio

9 A montagem espacial, em que o tempo se distribui no espaço é própria da disposição dos elementos na página web. Manovich (Silva, 2007) lembra que essa montagem já era característica dos afrescos e das histórias em quadrinhos. Mais ainda, esse modo de montar também se estende à cultura e à ciência, que estava mais acostumada a abordagens históricas e privilegia agora termos como geopolítica e globalização, entre outros conceitos que apontam para as teorias da pós-modernidade. $\mathrm{O}$ autor pensa também como montagem espacial as multitarefas realizadas em múltiplas janelas abertas, transformando assim a tela no que Foucault (1984) definia como espaços outros, espaços que registram simultaneidades e justaposições. Essa espacialização tem mais a ver com os modos de perceber a vida na contemporaneidade já que a nossa experiência no mundo estaria menos próxima de uma longa vida que se desenvolve no tempo e sim de uma rede que acontece no espaço. 
usuário, essa opção é destaque na barra de navegação lateral, reforçando na barra superior os sentidos de trânsito e formação de banco de dados por esse trânsito. O usuário é alguém que habita um mundo de dados audiovisuais habitáveis e, na medida em que os habita, forma suas coleções que passam a ser a principal moldura do território/canal. Ou seja, o usuário (e este pode ser um amador em vídeo ou uma grande empresa de comunicação) é um flanêur da plataforma e um colecionador. Isso, em termos de produção de sentido, dilui as grandes diferenças que há entre os usuários em relação ao seu domínio da produção audiovisual.

\section{Figura 2c: Barra de navegação vertical da home}

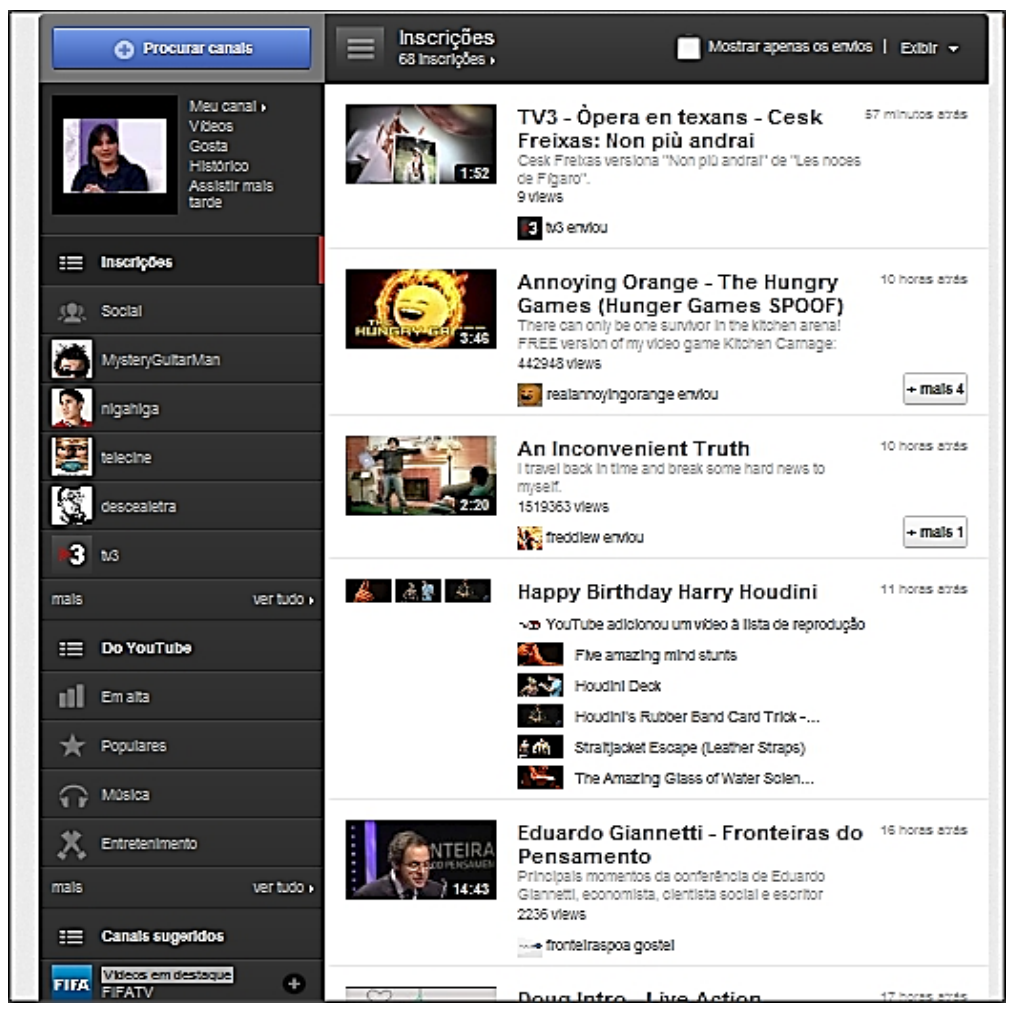

Fonte: YouTube, 2012.

Já no mesmo design de interface, a barra lateral (que lembramos está exclusivamente na home e não nas outras páginas, ver figura 2c), dá ao usuário e à plataforma sentidos relacionados à uma grande rede social que vincula usuários com usuários, usuários com vídeos e vídeos com vídeos, assim como usuários e vídeos a outras plataformas da web. Esta barra de navegação tem destaque no topo para o link "procurar canais", traz também a foto e listas de vídeos do 
usuário assim como as inscrições aos canais os quais o usuário é seguidor. A mesma barra traz um link para outros espaços do YouTube como "em alta" ou "do YouTube", molduras que colocariam o usuário em contato com vídeos e outros links que não fazem parte de suas coleções ou inscrições. Essa barra constrói o usuário em relações enunciadas como "locais" (seu próprio canal, suas preferências) e "globais" (aqueles vídeos mais vistos na plataforma ou as novidades que esta lhe oferece).

No design de interface de 2012, então, o usuário tem um espaço maior na home que no design anterior e é enunciado como um flâneur audiovisual, um habitante de uma grande metrópole audiovisual local e global na que lhe são oferecidos caminhos claros para criar relações com seus outros, seus "vizinhos", principalmente através da interação com seus vídeos.

\section{Figura 3: Home do YouTube em 2016}

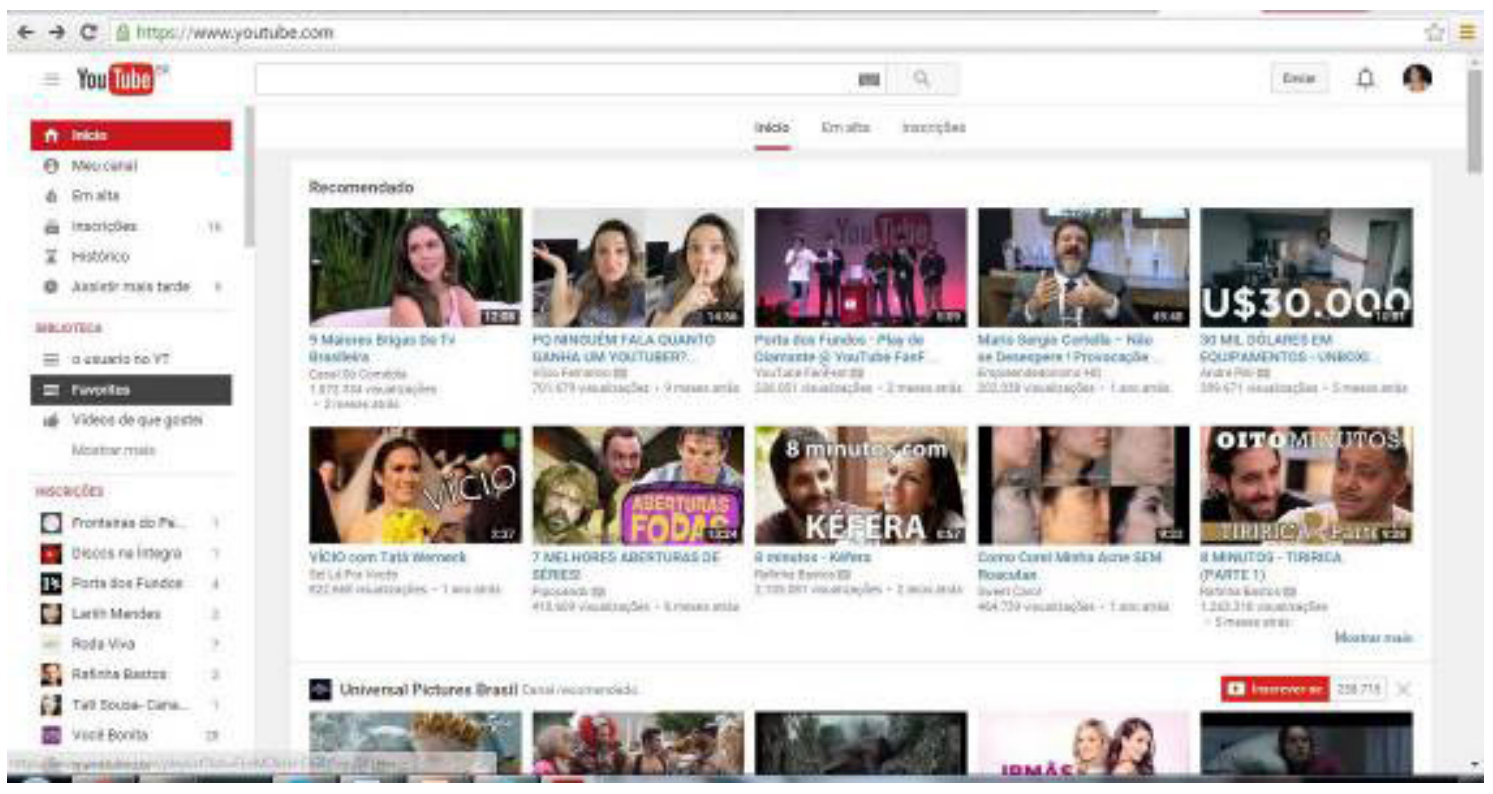

Fonte: YouTube, 2012.

A interface atual do YouTube (Figura 3), que vem sendo construída desde 2014, parece ter naturalizado uma série de sentidos cuidadosamente construídos nas interfaces anteriores e introduziu novos significados visíveis, particularmente na barra de navegação do usuário. O botão do usuário/canal aqui está mais estilizado trazendo os mínimos elementos: só a foto em um pequeno círculo, sempre na localização do canto superior direito. Ao apoiar o mouse abre uma aba com algumas informações e links num design bem mais limpo que as interfaces anteriores. A foto do usuário, acompanhada do 
email dele e seu nome e sobrenome (e não mais o seu login), traz uma certa "identificação", um fato inédito em relação às outras interfaces: "um assinante" (ver Figura 3a).

Figura 3a: detalhe de aba do usuário na barra de navegação superior da home do YouTube em 2016

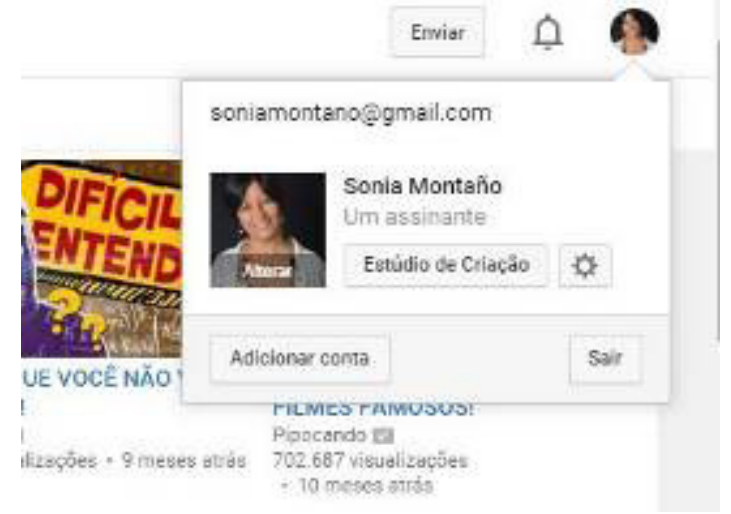

Fonte: YouTube, 2012.

Moldurado dessa forma, o usuário é hierarquizado ou no mínimo identificado em relação à produção audiovisual (ou ausência dela). O usuário específico da figura 3a é um assinante, alguém que assiste mais do que produz ou alguém que produz, mas suas produções não são um sucesso de público. O fato de produzir vídeo passa a ter importância decisiva na significação do usuário da interface atual e isso se reforça principalmente com o link "estúdio de criação". O link vai direto para o que seria o território do canal, só que no lugar de abrir o espaço de vídeos ou de inscrições do usuário vai à página, dentro do canal, onde o usuário pode editar ou criar vídeos e, inclusive, transmitir ao vivo. Nessa página, é fornecido um conjunto de ferramentas como trilhas, efeitos sonoros e um editor de vídeo, entre outras.

Há ainda uma última linha, em cinza mais escura com dois links: "adicionar conta" e "sair". O incentivo a ter mais de uma conta é principalmente o caso de alguns canais que passam certo número de inscritos e que para continuar eles precisam abrir mais um canal. Na home atual desapareceu a moldura com listas de vídeo, embora elas continuem existindo no território do canal. A barra de navegação lateral também mudou. Sem tanto destaque (fundo branco em lugar de preto), sem a foto do usuário ela continua tendo links para o próprio canal, as listas de vídeos e as inscrições, mas, os botões estão organizados em três grandes grupos: início, "biblioteca" (com as listas de vídeos) e "inscrições" com a lista de canais aos quais o usuário está inscrito. 
O canal, transformado em um "estudo de criação" e com uma estética mais limpa é agora um espaço que não simplesmente "envia vídeos", ele os "cria", acompanha suas visualizações e recebe uma série de dicas para criar um público, é instruído para aderir ao programa de monetização e sobre como usar a logomarca da plataforma, além de ter a opção de transmitir ao vivo. Há uma ressignificação do usuário que o relaciona a sentidos de produtor profissional de vídeo, ou pelo menos, aprendiz de realizador audiovisual num mix de hobby e trabalho.

\section{O USUÁRIO COMO CONSTRUTO INSTITUCIONAL}

Além da home, outro espaço onde particularmente é enunciado o usuário como centro da plataforma está nas páginas institucionais. $\mathrm{O}$ acesso a elas está principalmente pela barra de navegação inferior, mas há diversos links em toda a interface que levam a estes espaços. Trata-se daquelas páginas que fornecem instruções específicas para o usuário no YouTube de como usar a plataforma e, de alguma forma, prometem convertê-lo em realizador audiovisual, artista e empreendedor: o youtuber, um profissional da plataforma cuja criação de vídeo se torna um jogo/trabalho sem delimitações específicas entre um e outro.

Se na interface de 2012 os espaços institucionais se davam muito na convocação de certas campanhas ${ }^{10}$ que enunciavam principalmente uma força global mobilizadora de usuários, em 2016 a interface vem apontando para a criação de espaços institucionais que formam para o exercício de uma profissão remunerada. Essas enunciações, inclusive, reciclam imaginários próprios das instituições de ensino profissional com categorias como "escolas", "lições e cursos", "bibliotecas", e até com direito a "testes de conhecimento" e "certificados de conclusão", entre outras. Mas também essas enunciações convocam imaginários provindos do mundo empresarial como "veja casos de sucesso"; "transforme sua criatividade em sua carreira", entre outros.

A profissionalização do amador e a disponibilização de meios para auxiliar em todo o processo do que se está tornando cada vez mais conhecido com o nome de youtubers ou "criadores de conteúdo" passa a ser o centro das páginas em questão. Não há propriamente uma valorização de referências audiovisuais clássicas do cinema ou da TV para moldurar esse usuário produtor. As referências são internas à plataforma, canais de sucesso (com grande número

10 Lembramos como, em 2010, o YT aderiu ao que se chama de "Hora do Planeta", pedindo aos usuários para desligar a luz por uma hora, incluindo um interruptor na sua interface ao redor do vídeo, ou a campanha "A vida em um dia". Tratou-se de uma experiência global de um longa-metragem gerado por usuários: um documentário, filmado em um único dia, que todos os usuários foram convocados a gravar no dia 24 de julho de 2010. 
de visualizações) e aplicativos desenvolvidos e bem aplicados para melhorar a produção de vídeos e a criação de público dentro da plataforma. Ser um criador é ter um público cativo com vídeos que passam a ter anunciantes e um ganho monetário por visualização.

\section{Figura 4: interface da página Escola de Criadores de Conteúdo}

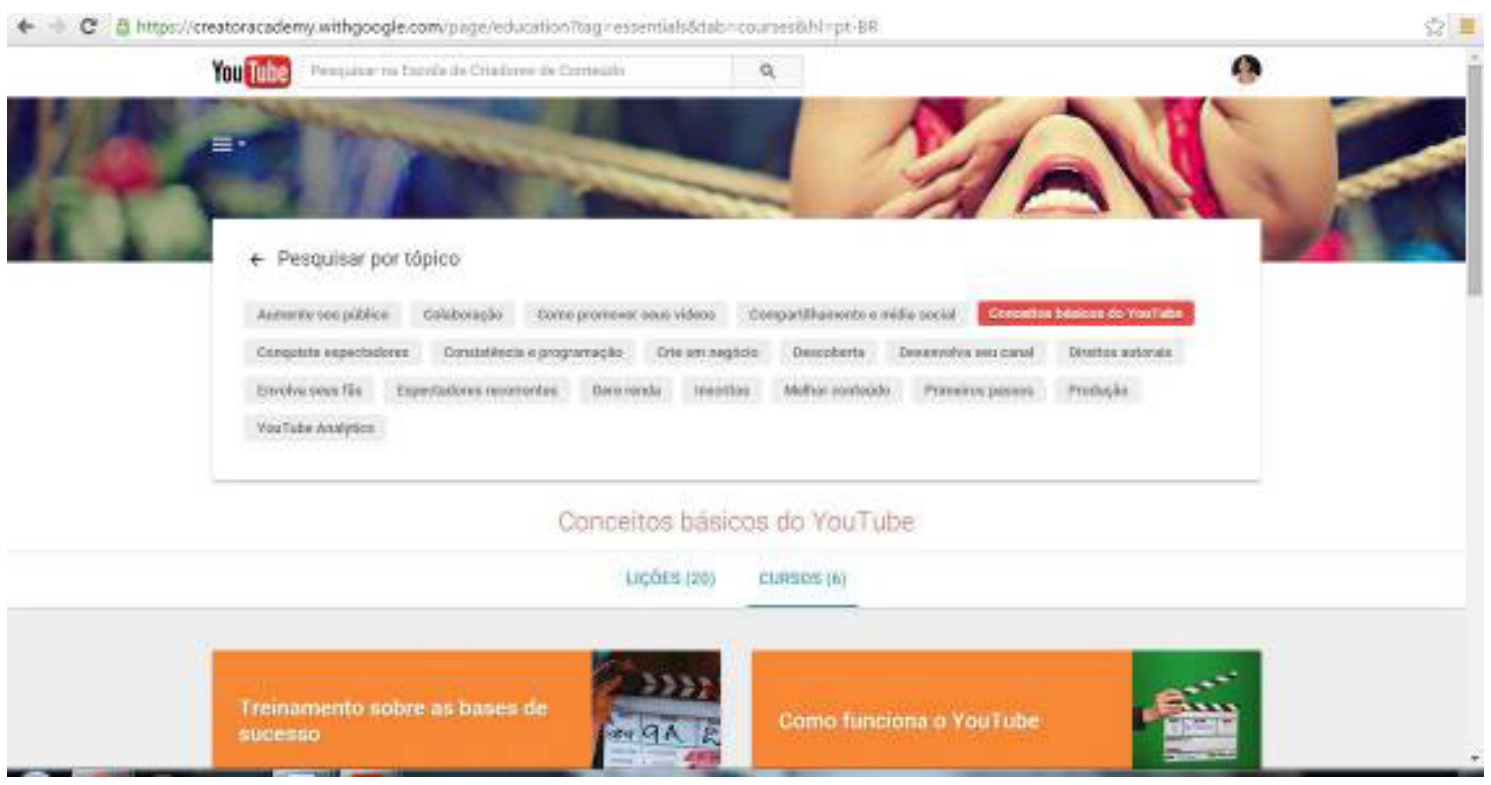

Fonte: YouTube, 2016.

As principais páginas em que a plataforma constrói esses usuários parecem ser "criadores", "desenvolvedores" e o"Testube". Essas páginas disponibilizam uma série de dicas de como ter um canal com identidade própria; como aproveitar ao máximo as ferramentas oferecidas e usar aplicativos criados por parceiros para esse canal. No caso do Testube, são disponibilizadas ferramentas novas, reforçando os sentidos de estado beta (constante atualização tecnológica testada pelo usuário) próprio da web 2.0.

O usuário passa a ser construído nestas páginas como aquele que desenvolve conteúdo, não importa qual (ver na figura 4 a interface da "Escola de criadores de conteúdo" e na figura 4a a página "desenvolvedores"), testa e utiliza uma série de recursos para que esse conteúdo atinja um determinado número de usuários (no caso "assinantes" de seu canal) e um colaborador para melhorar o universo audiovisual da plataforma. Essas páginas têm um design muito mais limpo, estetizado que as outras páginas do YouTube em que o vídeo principal, os relacionados, os botões ao redor do player e as propagandas dentro e fora do vídeo parecem brigar pelo espaço disponível, saturando o panorama com a sobreposição de imagens das mais diversas naturezas. 


\section{Figura 4a: interface da página YouTube para desenvolvedores}

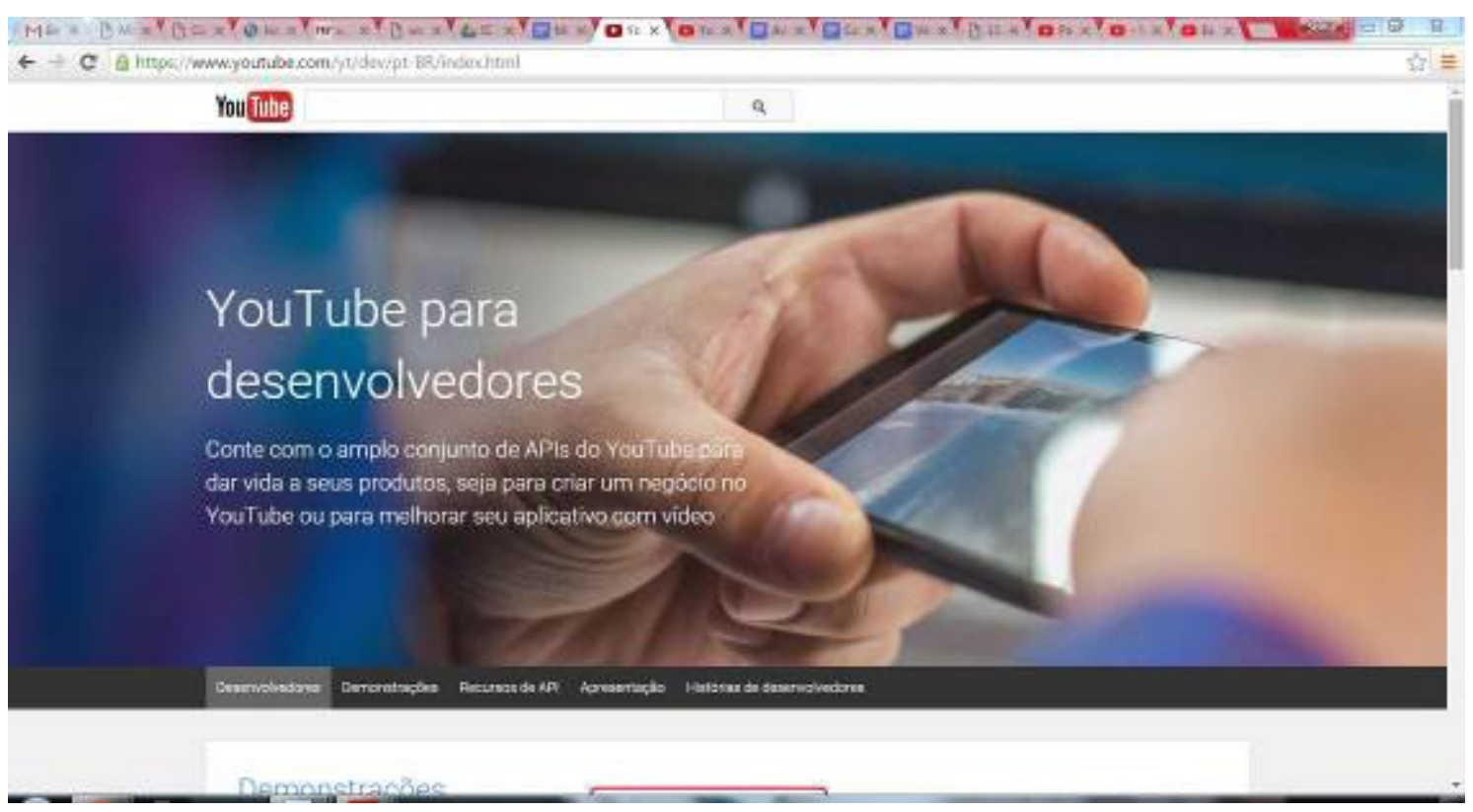

Fonte: YouTube, 2016.

A estética dessas páginas institucionais lembram mais o que Manovich (Silva, 2007, n.p.) chama de infoestética ou estética da informação, uma certa prática na qual se busca "dar sentido à informação, trabalhar com ela e produzir conhecimento a partir dela". Ela enunciaria a vida na sociedade da informação como uma experiência que se dá através do design, das texturas, composição, estrutura, construção, sensibilidade e outras dimensões artísticas "do seu design, textura, composição, estrutura, construção, sensibilidade e outras dimensões artísticas" (Silva, 2007, n.p.).

Seria uma estética que combina a racionalidade do modernismo com a racionalidade da programação diferente, por exemplo, da estética das listas telefônicas, pensada pelo autor como uma infoestética precedente. A infoestética expressa leveza, curiosidade e inteligência, conforme o autor, e lembra a vida produzida em algum laboratório de biotecnologia, uma vida que se regenera e não conhece a morte, desde que seu computador se mantenha conectado à rede. Essa estética leve, sem gravidade é, nessas páginas, uma moldura que marca decisivamente os sentidos dados ao usuário: um profissional da informação que sussurra entre texturas leves e formas texturizadas.

Criadores e desenvolvedores são assim um pouco artistas, um pouco arquitetos e engenheiros, um pouco cientistas e, sobretudo, empreendedores numa construção estética que recicla o imaginário das instituições mais 
tradicionais (como a escola de formação profissionalizante) às empresas formadoras de líderes. Esses criadores de conteúdos seriam empreendedores globais, profissionais da informação audiovisual que não obedecem a um território nacional. Eles têm seus "assinantes", aquele público que vê esses vídeos e aprendem as métricas do canal, as estratégias de fidelização de público e as diferenças, por exemplo, entre produzir para o YouTube e para a TV. A escola de criadores e o próprio estúdio de criação passa a ser o programa, no sentido dado por Flusser (2002) do usuário nos modos como é moldurado nestes espaços.

\section{USOS E APROPRIAÇÕES NA INTERFACE}

Haveria ainda um espaço no qual consideramos importante observar a construção do usuário: é nos usos e apropriações que acontecem no fluxo da interface e que se enunciam nesse fluxo. Se a interface é para Johnson (2001, p. 9) o universo de relações que fazem o funcionamento de alguma coisa, "o mundo imaginário de alavancas, canos, caldeiras, insetos e pessoas conectados - amarrados entre si pelas regras que governam esse pequeno mundo", o lugar de compreender a interface de um meio qualquer é no cotidiano, entrando no seu fluxo. O modo em que o meio é usado no dia a dia de forma já habituada é um "lugar" privilegiado para compreender esse meio, mas só é possível perceber suas montagens, desnaturalizando esse olhar para o qual o meio nos habitua.

Em observações diversas nos últimos seis anos, viemos constatando algumas práticas que podemos pensar quase como gêneros próprios da plataforma que resultam da repetição e da apropriação dos usuários. São eles: os memes, ${ }^{11}$ os vlogs, ${ }^{12}$ os "tutoriais", ${ }^{13}$ as webséries, ${ }^{14}$ programas de humor ${ }^{15} \mathrm{e}$

11 Seguindo Dawkins (2007), poderíamos pensar na memética como a lógica contrária à da criação, processo de produção e circulação sem líder, sem projeto, sem compreensão previa, ela é posterior. O meme tem um poder replicador, como o gene; ele se espalha entre diversas mentes. No caso do audiovisual nas plataformas, memes são aquelas experiências que tendem a se tornar conhecidas, copiadas, parodiadas, compartilhadas muito rapidamente.

12 Vídeos postados com certa periodicidade, geralmente com um enquadramento único do videologger, sujeito que discorre sobre um assunto específico.

13 O YouTube tem inúmeros vídeos que ensinam a fazer alguma coisa: desde uma receita de cozinha, usar um software, alisar o cabelo ou aliviar a dor de ciático. Chama a atenção para a presença massiva desses vídeos no YT, e acredito que eles tenham a ver com uma certa apropriação da técnica: de uma técnica qualquer que se dá a ver na técnica audiovisual. A emergência deste gênero parece enunciar que há sempre alguma questão na qual podemos ser professores. A construção de uma ethicidade, um certo tutorial ou "passo a passo" acentua ao mesmo tempo o processual e o absolutamente compreensível em vistas a sua realização é um sentido que atravessa as próprias plataformas de vídeo e a web em geral.

14 Trata-se de um fenômeno emergente na web em geral e nos sites de TV on demand em particular. Ver por exemplo as seguintes webséries feitas para o YouTube: https://www.youtube.com/user/ tiksmikswebseries ou https://www.youtube.com/playlist?list=PLyJcvc5BFG5TIOJJ4Xd8dE1NC5AxqJBsb 15 Um canal muito bem-sucedido em termos de público no YouTube é o Porta dos Fundos com comédias de curta duração (geralmente entre 2 a 4 minutos) em que um tema específico que dá título à história é satirizado, o vídeo segue algumas práticas televisivas como a da vinheta de abertura 
de outros conteúdos em formatos curtos, além de vídeos com propósito de experimentação audiovisual, ${ }^{16}$ entre outros. Recentemente com a função de transmissão ao vivo alguns usos nesses sentidos estão sendo práticas mais cotidianas, como a transmissão de programas de rádio ao vivo, canais que atualizam a meteorologia e muitos outros; principalmente, o gameplay, gênero em que a tela se divide entre o jogo e o jogador que o está jogando em diálogo com o público que o assiste através de um chat.

O termo "gênero" é um tanto duro para pensar essas práticas, já que algumas delas podem ser agrupadas em várias das mencionadas. Há youtubers que jogam videogame e conversam com seu "público" sobre o que fizeram no dia ou desenvolvem um tema específico (algo mais próprio do vlog). Há canais que diariamente gravam vídeos sobre maquiagem que podem ser pensados no gênero tutorial, mas também realizam uma verdadeira performance de comédia além de usarem enquadramentos e montagens que são mais próprios da comédia do que do tutorial, por exemplo. Podemos pensar nessas características como molduras de diversos gêneros que muitas vezes coexistem, embora alguma moldura sempre demarque um sentido identitário predominante de tal ou qual gênero.

Os usos no fluxo da interface criam uma verdadeira comunidade de referências mútuas, e de produções para públicos específicos, instigante para compreender toda uma rede de sociabilidades em que o audiovisual está no centro. Dentro destes usos também, ao pensarmos estritamente na produção de vídeos, há aqueles que buscam testar todos os limites e as possibilidades da plataforma e que são particularmente interessantes para pensar o audiovisual nas suas formas e montagens nesse meio.

Conforme comentado, usos e apropriações são construtos na interface (aqueles que acabamos de mencionar) e da interface: enunciações específicas sobre usos e apropriações.

Se voltarmos o olhar às homes do YouTube dos últimos três designs podemos compreender melhor essas ethicidades. Links como "mais vistos" e "vídeos do momento" ocupavam espaços importantes na home da interface de 2010, moldurando os usos com aqueles sentidos meméticos de cópia ou paródia, gênero que geralmente ocupava os mais vistos na época. Já em 2012,

e encerramento do canal. Em novembro de 2015, a equipe do Porta dos Fundos recebeu o Play de Diamante, a maior recompensa dada pelo YouTube aos criadores de conteúdo que alcançam a marca de 10 milhões de inscritos.

16 Ver por exemplo o canal do MysteryGuitarman, do brasileiro Joe Pena, em que as mais diversas linguagens audiovisuais são experimentadas e testadas na plataforma. O canal contém produções que problematizam a interface web, a plataforma e o audiovisual de maneiras extremamente instigantes, reprogramando (em termos flusserianos) a plataforma. 
a interface tirou o protagonismo desse tipo de prática (embora ela continue existindo e com maior intensidade, inclusive), dando, conforme comentado, maior espaço ao usuário como um sujeito (específico, com sua foto em duas barras de navegação) que, principalmente, anda na plataforma e coleciona vídeos e se relaciona com outros usuários através da inscrição nos seus canais. Os usos nesse segundo momento se identificam muito com a construção de coleções e com a interação com outros usuários. O design de interface atual parece sugerir que os usos estão mais devidamente organizados em "bibliotecas" (onde aparecem as listas de vídeos colecionadas) e em espaços especificamente para a criação com a disponibilização de ferramentas para essa finalidade.

A home e a interface em geral da plataforma parecem ser ao longo de sua história um lugar privilegiado de construção identitária de usos (e, portanto, também dos usuários), entretanto resulta muitas vezes contraditório com outro espaço em que essa enunciação acontece: os usos efetivos, as redes de vídeos, comentários, temas, respostas, novas práticas e experimentações dos espaços e das sociabilidades audiovisualmente mediadas que acontecem no dia a dia da plataforma.

\section{CONSIDERAÇÕES FINAIS}

Com 11 anos de existência (nove no grupo Google), a plataforma de vídeos foi construindo diversos sentidos identitários para si e para seu usuário. De "repositório de vídeos", como se autodefinia quando surgiu como um canal extraoficial que dava o mesmo acesso a artistas, grandes grupos de comunicação e um amador qualquer, todos com direito a "canal" na plataforma, passa a se enunciar hoje principalmente como o espaço de uma nova profissão, a do youtuber.

Conforme já comentado, a perspectiva de pensar o usuário como uma ethicidade ou construto no YouTube, permite-nos pensá-lo com Bergson (1999) como uma duração, isto é, uma multiplicidade virtual e não uma sequência evolutiva. Há uma coexistência de usuários enunciados que forma uma imagem densa, complexa e contraditória.

Ao olharmos para o usuário no YouTube podemos compreender alguns dos seus programas e inclusive de seus metaprogramas; contudo, é difícil afirmar ainda algumas questões decisivas sobre o tipo de tecnocultura criada na plataforma e os modos como o usuário se apropria da técnica. Enquanto alguns usos e apropriações parecem fazer avançar a técnica, as enunciações oficiais da interface parecem delimitar territórios que transformem o usuário em um produtor com características sui generis, mas reproduzindo os abismos industriais. Enquanto a estética da informação parece enunciar um profissional 
de última geração que habita um mundo de dados, limpo e minimalista, a plataforma recicla imaginários clássicos de ensino, de escolas e manuais onde o usuário se gradua e se torna um caso de sucesso. Enquanto alguns usos e apropriações criam verdadeiros processos que imaginam e codificam imagens técnicas que correspondem a uma nova imaginação, sentidos cada vez mais empresariais e fórmulas passo a passo são dados para o sucesso.

Em que sentido a técnica inclui o usuário do YouTube e dissolve quais muros entre autor e público? Em que sentido os modos de construir o usuário reforça muros historicamente construídos entre produtores e consumidores com novas imagens e imaginários que não eram próprios do mundo audiovisual? Que conceitos de mundo as diversas imagens técnicas do usuário no YouTube estão inscrevendo em superfícies que interfaceiam usuários, vídeos, trabalho, lazer, local e global, como tempos muito diversos vividos em um mesmo espaço que se compõe de dados e se mostra com uma estética da informação?

Este estágio da técnica parece ser particularmente contraditório e por isso particularmente fértil para a pesquisa no audiovisual contemporâneo, que passa privilegiadamente pelas plataformas de vídeo e nelas pela enunciação do usuário.

\section{REFERÊNCIAS}

ARAÚJO, Cleber. Atividade intelectual na modernidade em Walter Benjamin. Dissertação (Mestrado em Filosofia) - Setor de Ciências Humanas, Letras e Artes da Universidade Federal do Paraná, Curitiba, 2008.

BENJAMIN, Walter. Obras escolhidas I. Magia e técnica, arte e política. São Paulo: Brasiliense, 1996.

BERGSON, Henri. Matéria e Memória. São Paulo: Martins Fontes, 1999.

BRUNO, Fernanda. Dispositivos de vigilância no ciberespaço: duplos digitais e identidades simuladas. Revista Fronteiras - estudos midiáticos. v. 8, n. 2, p. 152-159, mai/ago 2006.

BURGUESS, Jean; GREEN, Joshua. YouTube e a revolução digital. São Paulo: Aleph, 2009.

CERTEAU, Michel de. A invenção do cotidiano, as artes do fazer. Petrópolis, RJ: Vozes, 2001.

DAWKINS, Richard. O gene egoísta. São Paulo: Companhia das Letras, 2007.

EISENSTEIN, Sergei. O sentido do filme. Rio de Janeiro: Jorge Zahar, 1990. 
FLUSSER, Vilém. Filosofia da caixa preta. São Paulo: Relume Dumará, 2002.

FOUCAULT, Michel. De los espacios otros. Conferencia pronunciada por Foucault no Cercle des études architecturals, em 14 de março de 1967. Architecture, Mouvement, Continuité, n. 5, out. 1984. Disponível em: http://www.scribd. com/doc/18767939/De-los-espacios-otros-Michel-Foucault Acesso em: 16 set. 2016.

JOHNSON, Steven. Cultura da interface. Rio de Janeiro: Jorge Zahar, 2001.

KILPP, Suzana. A traição das imagens. Porto Alegre: Entremeios Editora, 2010.

MANOVICH, Lev. A prática da vida (midiática) diária. Revista Lugar Comum, Rio de Janeiro, n. 28, p. 284-296, dez. 2011. disponível em: http://uninomade.net/wpcontent/files mf/111102120410lugarcomum 28 completa.pdf Acesso em: 4 nov. 2012.

MANOVICH, Lev. El software toma el mando. Barcelona, UOC Press, 2014.

O'REILLY, Tim. O que é web 2.0? Padrões de design de modelos de negócios para a nova geração software. 2005. Disponível em: https://pressdelete.files.wordpress. com/2006/12/o-que-e-web-20.pdf Acesso em: 29 out. 2015.

GROSSMAN, Lev. Person of the year. Time. December 25, 2006, v. 168, n. 26. Disponível em: http://content.time.com/time/magazine/article/0,9171,1570810,00.html Acesso em: 25 set. 2015.

PRIMO, Alex. Enfoques e desfoques no estudo da interação mediada por computador. LIMC, Porto Alegre, n. 45, 2005. Disponível em: http://www.ufrgs.br/limc/PDFs/ enfoques desfoques.pdf Acesso em: 2 jan. 2010.

SANTAELLA, Lucia. Linguagens líquidas na era da mobilidade. São Paulo: Paulus, 2007.

SILVA, Cícero Inácio da. A era da Infoestética. Entrevista com Lev Manovich. Revista Tropico. São Paulo, 2007. Disponível em: http://www.revistatropico.com.br/ tropico/html/textos/2928,1.shl Acesso em: 12 set. 2016.

TOFFLER, Alvin. A terceira onda. Rio de Janeiro: Record, 1980. 